\title{
The Effectiveness of Study Tour Towards Students' Speaking Skill
}

\author{
Indah Afrianti \\ Program Studi Pendidikan Bahasa Inggris, STKIP Yapis Dompu \\ E-mail: indahgracilaria@gmail.com
}

Article History: Received: 2021-01-05 || Revised: 2021-02-15 || Published: 2021-04-09

Sejarah Artikel : Diterima: 2021-01-05 || Direvisi: 2021-02-15 || Dipublikasi: 2021-04-09

\begin{abstract}
Students' speaking skill is not only determined by the teaching and learning process in the classroom, but it is also influenced by some factors such as facilities, purposes, motivations and learning environment. This research has been found out the effectiveness of study tour towards students' speaking skill for the second year of SMKN 2 Selong. This research was categorized as quantitative research by using experimental design that used to investigate and analyze the data which is obtained after giving the treatment of study tour toward the student speaking skill. Target population of this study was all of the second year of 2011/2012, which was consisted of student 100 students. The sample of the study was the students of II tourism department (UJP), consist of 30 students and it was categorized into the students who followed and did not followed study tour (experimental group and control group) each of them 15 students. This research of data collecting was study tour in Labuhan Haji. This research instrument of the study was oral test. In testing the hypothesis of this study utilized the t-test. Referring to the result of the oral test from 30 students of the second year of SMKN 2 Selong. The present research gained the data that the student who achieved the learning mastery in speaking. The result of t-test higher the t-table $(6.299>2.05)$ while in study tour, the result of $t$-test higher than $\mathrm{t}$-table (2.496>2.05), it means that alternative hypothesis was accepted.
\end{abstract}

Keywords: Effectiveness, Study tour, Speaking skill

\begin{abstract}
Abstrak
Keterampilan berbicara siswa tidak hanya ditentukan oleh proses belajar mengajar di dalam kelas, tetapi juga dipengaruhi oleh beberapa factor antara lain: fasilitas, tujuan, motivasi, dan lingkungan belajar. Penelitian ini bertujuan untuk mencari seberapa jauh keefektifan dari program studi perjalanan wisata terhadap keterampilan berbicara siswa khususnya kelas II SMKN 2 Selong. Penelitian ini di kategorikan sebagai penelitian quantitative yang menggunakan desain experimental menganalisis data yang diperoleh setelah memberi perlakuan studi perjalanan wisata terhadap kemampuan berbicara siswa. Jumlah populasi penelitian ini ditargetkan untuk seluruh siswa kelas II pariwiwata SMKN 2 Selong tahun pembelajaran2011/2012, yang terdiri dari 100 siswa. Sampelnya adalah siswa kelas II Usaha Jasa Pariwisata (UJP), yang terdiri dari 30 siswa dan yang termasuk dalam siswa yang ikut dan tidak ikut program study perjalanan wisata (grup experimental dan grup kontrol) masing-masing 15 siswa. Pengumpulan data pada penelitian adalah studi perjalanan wisata di Labuhan Haji. Instrument penelitiannya adalah tes lisan. Di dalam menguji hipotesis penelitian ini menggunakan rumus t-test. Berdasarkan hasil teslisan dari 30 siswa kelas II SMKN 2 Selong. Peneliti ini memperoleh data bahwa siswa yang mencapai penguasaan belajar di dalam berbicara, hasil dari t-test lebih tinggi daripada t-table $(6.299>2.05)$ dan di dalam study perjalanan wisata hasil dari t-test lebih tinggi dari ttable (2.496>2.05), itu menunjukkan bahwa, hypothesis alternative itu diterima.
\end{abstract}

Kata kunci: Keefektifan studi, Perjalanan wisata, Keterampilan berbicara

\section{INTRODUCTION}

English is the most widely used of language in the world. It means that, English has hold very important role in many aspects of international affairs as English is needed because means of 
international communication. English plays the main role in the international interaction and relationship among the people of one country visited by other people from other countries. Makes the people aware to master English as the international language. The relationship among the nation will be more complicated as many things can be communicated, discussed, and among the countries in the global interaction. English is categorized as a curriculum load as same as Indonesia language, Mathematics, and civics education which are programmed and facilitated since the junior high school into university level. This all has important implications for communicate actively as a speaker or passively as a writer.

There are four language skills, which are reading, listening, speaking, and writing. Reading and listening are receptive skills, and also speaking and writing are productive skills. Speaking is the productive skills in oral mode than the other skills. Speaking is more complicated than reading and listening because pronouncing words. Through speaking skills, students can ask and answer questions about various substance, engaged in a short conversation fluently, opinions, feelings and attitude, express the experiences, and communication with the native speaker in studying tour. A study tour is a travel experience with specific learning goals. The learning goals of each study tour vary, but are always spelled out in the course syllabus that is distributed to each learner. Study tours emphasize experimental learning and offer both group and self-directed activities that enable learners to explore new territories, cultures, and people. A Study Tour is a course combined with a short-term period of group travel designed to introduce you to other countries and cultures by bringing to life what you are learning in the classroom.

According to the Iwan Jajadi 2008 English Curriculum that the students are able to communicate in English by mastering the whole skills. However, it is not easy to master all the skills, so they must learn one important skill that covers the whole skills. Based on the statement above speaking is the most important skill that should be mastered by students in order to communicate in English fluently. In this case, the students must study hard to master English Speaking skill and the teacher should create a good atmosphere in the classroom. It is contrary to the real situation in the classroom. Speaking activities do not work in the classroom because many factors prevent students from speaking English with their friends. They are afraid of making mistakes, of being laughed by their friends and of having lack of confidence in their ability. Considering this event, relating to speaking activities in the classroom and helping the students towards their speaking skills is part of the teacher's job.

The researcher expected to have right teaching techniques to provide students with appropriate teaching materials in the classroom. The researcher as English teacher should create a positive outside classroom environment, so the students can practice their speaking skill comfortably and interestingly because of it. Here the teacher and the students have the same opportunity to use English. The teaching and learning process outside classroom should not only happen between teacher and students, but also between students and students, as well as between students and native speaker (foreign tourist). Outside of the classroom, the teacher should create the situation that can encourage real communication. Many activities can be designed to make major element lively.

The effectiveness of study tour program is one of the techniques that can be applied in teaching speaking because study tour is one of the educational tours offering an opportunity for a rich immersion experience and the tremendous way to facilitate learning. In study tour, students have changed to talk to native speaker and the students will be more confidence with the lesson that they have been gotten in the classroom to show that how far they can speaking English. And other definition of study tour is travelling education and visiting one place to another place or tourism object. Beside students can talk to native speaker, they can enjoy the panorama of beach, swimming and fun. This program aims to make the students can speak English easily, and can progress their 
emotion, courage, confidence, so that they assume that talking to the native speaker is common and easy to understand the native speaker saying directly in the real situation, and it can be proved by the researcher through the effectiveness of study tour towards the students' speaking skills for the second year of SMKN 2 Selong.

\section{RESEARCH METHOD}

The method of the study was the Quantitative and Experimental method. Every twice a weeks, through program of study tour, the students were invited to the tourism object for practice of speaking with native speaker, in the regarding the researcher invites the students to the tourism object, which is nearest from the school where she investigate. Before practice of speaking the students are giving introduction their identity to the teacher and their friends for the first meeting in study tour. After they speak to native speaker by themselves, they has been tell again their experiences during study tour. So, the reseacher as the teacher can research which among them are the most excellent in speaking skill and getting the best ending scores.

\section{A. Data source}

The researcher was took the tourism department class for the second year of SMKN 2 Selong as the participants to be involved in this research. Population of this study is the whole students' of the tourism department, this program consist of two classes for the second year students and divided in the experimentall class and control class. Based on the above statements, the researcher was took $15 \%$ from the number of population which consists of 100 students of the second grade of SMKN 2 Selong. So, the researcher was took 30 students as the sample in this study for each class. The researcher uses cluster random sampling technique to take the sample.

Cluster random sampling used to was determined when the object that was observed or data source very large (Sugiyono, 2008, p. 83). For determine the students that become a sample, so the sample is taking based on population total that appointed. Based on the above statement, from 30 students that become a sample, the researcher was took 15 students for experimental group and 15 students for control group as the following table.

\begin{tabular}{lc}
\hline \multicolumn{1}{c}{ Groups } & Number of Sample \\
\hline $\begin{array}{l}\text { Study tour } \\
\text { Participants }\end{array}$ & 15 students \\
\hline $\begin{array}{l}\text { Non-Study Tour } \\
\text { Participants }\end{array}$ & 15 students \\
\hline Total & 30 students
\end{tabular}

The sample determine above divided into the students who follow study tour are 15 students and the students who do not follow it are 15 student.

\section{B. Data Collecting}

After gaining significance data, the researcher comes to The steps that have been used in finding the data are as follows:

1. Before instructional activities, the researcher gave pre-test to the students.

2. While instructional activities, the students was taught by using study tour for experimental group while control group was taught by using oral test.

3. After instructional activities, the students gave post-test with the same test that is used in pre-test.

4. Finally, after post-test is administered, the researcher was continued the analysis of the students' work sheet to find out the individual score of students. 
a. Variable identification

Variable can be stated as anything that will be object of the research (Suharsimi, 2006, p. 118). There are two variables that are involved in this research. The variables are dependent and independent variable. In this case the dependent variable of this research is the oral test of students in speaking skills (Y). While the independent variable of this research is the effect of using study tour (X).

\section{b. Variable Definition}

In order to avoid misunderstanding among the readers, it is considered important to define some terms concerning with this research. The terms are as follows: (1) Study Tour is a course combined with a short-term period of group travel designed to introduce you to other countries and cultures by bringing to life what you are learning in the classroom.http://www.studytour.org/whatis.htm. (2) Speaking is an articulation of the sound to express thought. Tarigan (in Mahsin 2003, p. 21) says that speaking is the capability to articulate the sound expressing and delivering thought, opinion and wish.

\section{c. Instruments}

An instrument is absolutely important in finding out the result of research. So, the technique must be well prepared. The instrument used in this study is a test that used to get the score of students. Suharsimi (2006, p. 29) states that a test is set of question or exercise or other tools which is used to measure skill, knowledge, intelligence, achievement, aptitude of someone or a group of people.

In this study, the researcher used the oral test to measure the students' speaking skill for the second year XI. The oral test materials are essential and suitable with the students' grade and relevant to study tour program. The sum of the oral test items are 40 items test that has been completed with the instruction. The number of the oral test can cover the materials that has been given when the researcher teach speaking skill outside classroom or conducted treatment to both groups. (a) try-out (b) test validation (c) test reliability.

\section{Technique of Data Collection}

To obtain the data needed the reseacher programs once weeks instructional to the subject. The experimental groups of speaking practice of native speakers was took the study tour in the Labuhan Haji, while control group just practice in the classroom, and they did not follow of study tour. Here the researcher was compared between the students of experimental group and the students of control group. Due to the fact that, we can get the result of study tour program through the maximum scores.

However, be instructional activities, the two groups has been done test orally of the native speaker. For the sake of extent to measure the students previous oral productions, the researcher was helped by an English teacher SMKN 2 Selong hopefully he or she does oral interview to the students, the interviewing process has been done of group in three by several questions or (around 4 to 5 questions for each student). Once week the experimental groups are invited to the tourism object for speaking practice with native speaker. The element to be measured consists of; vocabulary comprehension, fluency, accent which receives the lowest, weighting, and grammar scale receives the heaviest weighting.

\section{D.Data Analysis}

Analyze by following the procedure:

\section{Normality Testing}

Consider these potential problems: 
a. Small samples almost always pass a normality test. Normality tests have little power to tell whether or not a small sample of data comes from a Gaussian distribution.

b. With large samples, minor deviations from normality may be flagged as statistically significant, even though small deviations from a normal distribution not affect the results of a t-test.

c. Identify the students' individual raw and final scores: from the students' result of interview, the reseacher can be easily listed down the students' scores into table student individual raw and final scores.

d. To obtain the information concerning of the students attainment, the study determined table of achievement scale and qualification as follows :

\begin{tabular}{lll}
\hline No & Percentage & Qualification \\
\hline 1. & $85 \%-100 \%$ & Very High \\
2. & $75 \%-84 \%$ & High \\
3. & $60 \%-74 \%$ & Sufficient \\
4. & $40 \%-59 \%$ & Low \\
5. & $0 \%-39 \%$ & Very Low \\
\hline
\end{tabular}

The test of hypothesis, it is used $\mathrm{t}$ - test with the level of significance 0,05 the formula of $\mathrm{t}$ - test is $: x^{2}=<x_{1}^{2}$ table.

\section{Hypothesis Testing}

Before testing the hypothesis, the researcher has been getting the students' score of the experimental and control groups. The scores were checked from:

a. Calculate the students individual mean score:

To calculate the students mean score the reseacher in study_used the formula:

$$
\pi=\frac{\sum x}{N}
$$

Notes:

$$
\begin{array}{ll}
\pi & =\text { The mean scores } \\
\mathrm{N} & =\text { The number of sample } \\
\sum \mathrm{X} & =\text { the sum of the subjects scores }
\end{array}
$$

b. Computation of the significant of different between the two mean score and deviation and deviation score with a t-test formula, which runs:

The test hypothesis, it is used $\mathrm{t}$ - test with the level of significance 0,05 the formula of $t$ - test is : $\quad x^{2}=<x_{1}^{2}$ table. (Suharsimi, 1993, p. 70)

$$
t=\frac{x-y}{\sqrt{\left(\frac{\sum x^{2}+\sum x^{2}}{N_{x}+N_{y}-2}\right)\left(\frac{1}{N_{x}}+\frac{1}{N_{y}}\right)}}
$$

Notes:

$\mathrm{N}=$ the sum of the subject

$\mathrm{M}=$ the mean scores of each group

$\mathrm{X}=$ the deviation of each Value $\boldsymbol{x}^{2}$

$\mathrm{Y}=$ the deviation of value $\mathrm{y} 2$

And then, the criterion will be used is as followed:

1. If $\mathrm{t}$ - test $(\mathrm{tt})>\mathrm{t}-$ table (to) in significant rank of 0,05 , Ho (Null Hypothesis) is rejected. It means that the rates of mean scores of the experimental group are higher than the control group. 
2. If $\mathrm{t}-$ test $(\mathrm{tt})<\mathrm{t}-$ table (to)in significant rank of 0,05 , Ho (Null Hypothesis) is accepted. It means that, the rates of mean scores of the experimental group are lower than the control group

\section{RESULTS AND DISCUSSION}

\section{A. Result}

To get the data on the students' ability in speaking ability, the research gratitude to the headmaster of SMKN 2 Selong for his help to give permition to conduct this research. Firstly, the researcher formerly came to the sample classes and delivered a kind of pre-test explore, sample speaking skill. In this regarding the students gave a short direct interview which is concern to the tourism object, some of them so strange and even confused. Occasionally the research tried to ask a question about the tourism object in Indonesia especially the places the nearer from their living in the East Lombok - West Nusa Tenggara.

When the process of interview, the researcher is helped by English teacher of SMKN 2 Selong gave the value score or mark to the students' speaking performance, to suffer the system of scoring the researcher under the help of an English teacher used the guidance which is issued by (Heaton, p. 1975) consist excellent, very, good, satisfactory enough, fairly and terrible but meanwhile the researcher will not used by Heaton because be realized that our students who sit in vocational high school (SMKN 2 Selong) include to the beginner learner. Excellent are intent in this particular research the students can express their idea, feeling, emission, desire and even their willingness and express orally according to their level.

The researcher conducted the researched respectively as have been know students sample are experimental group or students of second year (class IIUJP) are conducted with some topic discussion by using (native speaker) in speaking practice to achieve the target of language (English language) mean while the other from (class IIUJP) are conducted with the same topics but did not use the native speaker to achieve the target of language, it means that conventional or the system which use there. The discussion which concern with the topic of discussion as follow: (1) Asking about the interesting places, (2) Holiday, (3) Tourism object.

During the practice phase of lesson, students are given more of an opportunity to use the language in less controlled situation, but the teacher even on the lookout for grammatical and structural errors that comes from the basis of subsequent lesson. Organizing review is primary task for the teacher according to Pittman (936), who summarizes the teacher responsibility as dealing with: (1) Timing, (2) Oral practice, (3) Revision (review), (4) Adjustment to special need of individual, (5) Developing language activities other than those arising from the text book.

After consideration some scoring component system in this case especially the student's responses to give answer to the question are given by the teacher and examiner. However, is rather subjective sense that the score to the spoken task. To some extent, are carefully analyses to the component will result in the objective score too. Those scores are presented as follows:

1. Experimental group

The first table in an experimental that obtain from their second class (IIUJP) of SMKN 2 Selong.

Table 1. Table of computing the students' individual raw and final scores of experimental group.

\begin{tabular}{cccccc}
\hline \multirow{2}{*}{ No } & Students' Code & \multicolumn{2}{c}{ Raw score } & \multicolumn{2}{c}{ Final score } \\
\cline { 3 - 6 } & & Pre-test & Post-test & Pre-test & Post-test \\
\hline 1 & E1 & 3 & 4 & 5 & 6 \\
\hline 2 & E2 & 4 & 5 & 6 & 8 \\
\hline 3 & E3 & 3 & 4 & 5 & 7 \\
\hline 4 & E4 & 2 & 4 & 5 & 6 \\
\hline 5 & E5 & 3 & 4 & 5 & 7 \\
\hline
\end{tabular}




\begin{tabular}{cccccc}
\hline 6 & E6 & 4 & 5 & 6 & 8 \\
\hline 7 & E7 & 3 & 4 & 5 & 6 \\
\hline 8 & E8 & 3 & 5 & 6 & 7 \\
\hline 9 & E9 & 2 & 4 & 5 & 7 \\
\hline 10 & E10 & 2 & 4 & 5 & 6 \\
\hline 11 & E11 & 3 & 4 & 5 & 6 \\
\hline 12 & E12 & 3 & 5 & 6 & 7 \\
\hline 13 & E13 & 4 & 5 & 6 & 8 \\
\hline 14 & E14 & 4 & 4 & 5 & 7 \\
\hline 15 & E15 & 2 & 3 & 5 & 6 \\
\hline \multicolumn{2}{|c|}{ Total } & 45 & 64 & 80 & 102 \\
\hline
\end{tabular}

2. Control group

The second table is a control that obtain the second class (II UJP) of SMKN 2 Selong whose named of score are presented and make them up at control group individual score. The following table (2) concerns with the students of control group individual scores either of pretest or them their post-test result.

\begin{tabular}{cccccc}
\hline \multirow{2}{*}{ No } & Students' Code & \multicolumn{2}{c}{ Raw score } & \multicolumn{2}{c}{ Final score } \\
\cline { 3 - 6 } & & Pre-test & Post-test & Pre-test & Post-test \\
\hline 1 & C1 & 2 & 3 & 4 & 6 \\
\hline 2 & C2 & 3 & 3 & 5 & 5 \\
\hline 3 & C3 & 2 & 3 & 4 & 6 \\
\hline 4 & C4 & 3 & 4 & 5 & 6 \\
\hline 5 & C5 & 2 & 3 & 5 & 5 \\
\hline 6 & C6 & 4 & 5 & 5 & 6 \\
\hline 7 & C7 & 3 & 3 & 4 & 6 \\
\hline 8 & C8 & 4 & 4 & 5 & 6 \\
\hline 9 & C9 & 3 & 4 & 5 & 6 \\
\hline 10 & C10 & 3 & 4 & 5 & 6 \\
\hline 11 & C11 & 2 & 4 & 5 & 5 \\
\hline 12 & C12 & 3 & 3 & 4 & 5 \\
\hline 13 & C13 & 3 & 4 & 5 & 6 \\
\hline 14 & C14 & 2 & 3 & 5 & 5 \\
\hline 15 & C15 & 2 & 3 & 5 & 6 \\
\hline & Total & 41 & 53 & 71 & 85 \\
\hline
\end{tabular}

After obtaining the students raw and final score of both students sample pre-test and post-test of the raw groups (experimental group and control), the researcher should analyze the data in the table to find out the mean score, deviation scores and it is significant. But before to those the data analyses the researcher formerly need to state a working table to make easier his work with the formula delivered. The data 3 and 4 bellows deal with the students individual final score. Deviation scores and also the squarest of the students' individual deviation scores. Table 3 table of computing the students individual deviation score from man of experimental group.

\begin{tabular}{cccccc}
\hline \multirow{2}{*}{ No } & Students' Code & \multicolumn{2}{c}{ Score } & Standard deviation & \multirow{2}{*}{$1^{2}$} \\
\cline { 2 - 4 } & & $\mathrm{Xa}$ & $\mathrm{Xb}$ & & \\
\hline 1 & E1 & 5 & 6 & 1 & 1 \\
\hline 2 & E2 & 6 & 8 & 2 & 4 \\
\hline 3 & E3 & 5 & 7 & 2 & 4 \\
\hline 4 & E4 & 5 & 6 & 1 & 4 \\
\hline 5 & E5 & 5 & 7 & 2 & 4 \\
\hline 6 & E6 & 6 & 8 & 2 & \\
\hline
\end{tabular}




\begin{tabular}{cccccc}
\hline 7 & E7 & 5 & 6 & 1 & 1 \\
\hline 8 & E8 & 6 & 7 & 1 & 1 \\
\hline 9 & E9 & 5 & 7 & 2 & 4 \\
\hline 10 & E10 & 5 & 6 & 1 & 1 \\
\hline 11 & E11 & 5 & 6 & 1 & 1 \\
\hline 12 & E12 & 6 & 7 & 1 & 4 \\
\hline 13 & E13 & 6 & 8 & 2 & 4 \\
\hline 14 & E14 & 5 & 7 & 2 & 1 \\
\hline 15 & E15 & 5 & 6 & 1 & 36 \\
\hline
\end{tabular}

Table 4. table of computing the student's individual deviation score of the mean control group.

\begin{tabular}{|c|c|c|c|c|c|}
\hline \multirow[t]{2}{*}{ No } & \multirow[t]{2}{*}{ Students 'Code } & \multicolumn{2}{|c|}{ Score } & \multirow[t]{2}{*}{ Standard deviation } & \multirow[t]{2}{*}{$\mathrm{Y}^{2}{ }^{2}$} \\
\hline & & $\mathrm{Ya}$ & $\mathrm{Yb}$ & & \\
\hline 1 & C1 & 4 & 6 & 2 & 4 \\
\hline 2 & C2 & 5 & 5 & 0 & 0 \\
\hline 3 & C3 & 4 & 6 & 2 & 4 \\
\hline 4 & $\mathrm{C} 4$ & 5 & 6 & 1 & 1 \\
\hline 5 & C5 & 5 & 5 & 0 & 0 \\
\hline 6 & C6 & 5 & 6 & 1 & 1 \\
\hline 7 & C7 & 4 & 6 & 2 & 4 \\
\hline 8 & $\mathrm{C} 8$ & 5 & 6 & 1 & 1 \\
\hline 9 & $\mathrm{C9}$ & 5 & 6 & 1 & 1 \\
\hline 10 & C10 & 5 & 6 & 1 & 1 \\
\hline 11 & C11 & 5 & 5 & 0 & 0 \\
\hline 12 & C12 & 4 & 5 & 1 & 1 \\
\hline 13 & $\mathrm{C} 13$ & 5 & 6 & 1 & 1 \\
\hline 14 & C14 & 5 & 5 & 0 & 0 \\
\hline 15 & C15 & 5 & 6 & 1 & 1 \\
\hline & Total & 71 & 85 & 14 & 20 \\
\hline
\end{tabular}

\section{B. Discussion}

To discuss the data that obtained the researcher uses analyzes approach, and in this case to get the result, the researcher uses formula to compare its result to the table to find out the contribution. Firstly, the researcher uses some procedure in analyses the data that obtain:

1) Calculating the students mean score of the two groups.

The mean score of a distribution is commonly understood as the arithmetic average, it computed by dividing the sum all the score by the number of the sample (Jhon B West, p. 1992). If there is the greater the mean score obtain by the students taking certain kind of test, the more successful they are or vice versa. (Wiersma William, p.1985). To get the mean score of the two groups in this investigation, the researcher applied the following formula:

$$
\boldsymbol{\pi}=\frac{\sum X}{N} \quad \text { (Suharsimi, p. 1992) }
$$

Where:

$\boldsymbol{\pi}=$ the mean score of the group (x for experimental group and y for control group)

$\sum \mathrm{X}=$ the individual of final score (score in distribution)

$\mathrm{N}=$ the number of the sample

Furthermore the researcher come analysis by using formula that used by Suharsimi: 
a. The Ideal mean score of the experimental group.

In the table 3 it is identified that:
1) Pre-test $\sum X=80$
$\mathrm{N}=15$
2) Post-test $\sum X=102$
$\mathrm{N}=15$

b. The mean score of the experimental group is that:

1) Pre-test $=5.33$

2) Post-test $=6.8$

c. Control group

In the table 4 above, it is identified:

1) Pre-test $\sum X=71$

$$
\mathrm{N}=15
$$

2) Post-test $\sum X=85$

$$
\mathrm{N}=15
$$

The mean score of the control group is then:

1) Pre-tes $=4.73$

2) Post-test $=5.66$

2) Computing the students mean score of the two mean score

To compute the students standard deviation score of this investigation the researcher applies the following formula:

$\mathrm{Sd}=\sqrt{\frac{\sum x^{2}-\left(\sum x\right)^{2}}{\frac{n}{n-1}}}$

Where:

Sd $=$ The Score of Standard Deviation

$\sum \square^{2}=$ The Sum of Pre-Test and Post-Test of the Two Groups

$\sum \mathrm{X}=$ The Standard Deviation of Pre-Test and Post-Test of the Two Groups

$\mathrm{n} \quad=$ The Number of the Sample

The detail calculates as follows:

(Suharsimi, p. 1992)

a. Experimental group $=27.53$

b. Control group $=13.80$

3) Identifying the significance of the two score

Finally, in this statistical to find out the value $t=2.375$

$\mathrm{Df}=\mathrm{N}-1$

Where:

$\overline{\bar{\square}}=$ the mean score of experimental group

$\overline{\bar{\square}}=$ the mean score of the control group

$\sum \mathrm{X} 1^{2}=$ the standard deviation score of experimental group

$\sum \mathrm{Y}^{2}=$ the standard deviation score of control group

$\mathrm{NX}=$ the number of the sample

$\mathrm{NY}=$ the number of the sample

Note :

The result of t-test $=2.375$ and t-table $5 \%(d f=28)=2.05$. So, the effect is $2.375>2.05$, it indicates significant.

After calculating the data by using a t-test and the result is find 13.120 for speaking skill (Appendix 08) and 2.375 for study tour (it is above) all at once as the value of critical value of $t$. 
to test the significance of two variable are being investigated the critical value is compared to the t-table. t-Table is quoted from Suharsimi' book of ,"research procedure"(2006).

According to him if we don't find the certain degree of freedom. but fortunately the researcher found out the result of t-table on 40-60 under the confidence level $5 \%=2.05$. On this research the researcher find out the degrees of differences between the two mean score is significance enough at confidence levels. The result of t-test $=13.120$ and $t$-table $5 \%(\mathrm{df}=28)$ 2.05. So, the effect is $13.120>2.05$, it indicates significant (see appendix 08). And also the result of t-test 2.375 and $t$-table $5 \%(\mathrm{df}=28)=2.05$ so, the effect is $2.375>2.05$, it indicates significant.

\section{CONCLUSION}

From the critical value of this investigation the researcher infer that speaking practice with native speaker in studying tour is necessary to be done for the students speaking skill. Based on the treatment of two mean scores of experimental and control group with a t-test formula, it is obtained that the critical value t equals to 13.120 for speaking skill and 2.375 for study tour, this critical value is higher than that of degrees of freedom $400-60$ at confidence level $5 \%(\mathrm{df}=28)=$ 2.05 , and the level of significant got the result value of $13.120>2.05$ and $2.375>2.05$. In fact, the $t$ critical value is significance for both confidence levels. And finally the researcher here takes the conclusion the null hypothesis (Ho), which states: speaking practice of native speaker during study tour can give new great, motivation, and toward the students speaking skill is clearly rejected, on the other hand the alternative hypothesis ( $\mathrm{Ha}$ ) is definite accepted. In this investigation the researcher could know about know about students capability in achieving accent, grammar, vocabulary, pronunciation, fluency, and comprehension case of speech.

\section{REFERENCES}

Drs. A.J muljadi,MM,dan Dra.Siti Nurhayati.(2003). Pengertian penelitian .khusus menulis pariwisata .tingkat dasar modul I. Pusat Pendidikan dan Penelitian Kebudayaan dan pariwisata.

Drs. H. Oka A.Yoety,M.BA (2006). Tour and travel marketing. Jakarta: Pradnya Paramita .cet.2

Iwan Jazadi Ph.D. (2008). The politics of curriculum An interpretive study of English language teaching and learning at high school in Indonesia. Published by paracendekia Nw press. Jl,Garuda Gang KaaryaIII Lampe Sumbawa Besar NTB. Printed in Indonesia.

Suharsimi, Arikunto. 2006. Prosedure Penelitian Suatu Pendekatan Praktik. Jakarta: Rineka Cipta.

Tarigan, Henry Guntur. 2008. Berbicara Sebagai Suatu Keterampilan Berbahasa. Bandung: Angkasa.

Nugroho Noto Susanto (2008). The contribution of speaking practice with native speaking practice with Native speaker toward students speaking skill capability: A case study At second year of SMAN 7 Mataram in the school year 2007/2008.Mataram Institute of Teacher Training Faculty of Education for Language and Art. Un published S-I Thesis

Nurul Hidayah.(2008). The effect of English speaking club (ESC) towards student' speaking ability for the second year of SMA NW Pancor in the school year of 2008-2009. Unpublished Undergraduate thesis, Hamzanwadi Selong College of Teacher Training and Education , Nusa Tenggara Barat, Indonesia.

A.Hari Karyono. (1997). Kepariwisataan. Jakarta: PT. Gramedia Widasarana Indonesia. 